\title{
Research on the Effects of Some Health Parameters of Regular Football Training
}

\author{
H. Bayram Temur \\ High School of Physical Education and Sports, Yuzuncu Y1l University, Turkey
}

Copyright $(2018$ by authors, all rights reserved. Authors agree that this article remains permanently open access under the terms of the Creative Commons Attribution License 4.0 International License

\begin{abstract}
With this study, it is aimed to investigate whether there is an effect on having regular football training, body weight, height and BMI values as well as cholesterol, HDL, LDL, Iron, Calcium, Sodium, Mean Cell Volume (MCV), Hemoglobin (HGB), Mean Hemoglobin Volume (MCV) Mean Cell Hemoglobin Concentration (MCHC), Platelet (PLT), Leukocyte-white blood cell (WBC) and Hematocrit (HCT). A total of 20 volunteer men, aged $25.31 \pm 5.28$ years, 10 of them playing football and ten Sedentary subjects, were included in the study. The average age of sports players playing football is $7.11 \pm 72$ years. Participants were taken to a health institution in the morning on an empty stomach and blood samples were taken. In addition, the subjects' height, body weight, and BMI were calculated. In the analysis of the obtained data, $t$ test was used in SPSS 21 package program. At the end of the study, it was seen that there was a difference between body composition and body weight at $\mathrm{p}<0.05$ and body length and BMI at $\mathrm{p}<0.01$ level. In blood parameters, sodium and HTC values were found to be different in $p$ $<0.05$ and $\mathrm{p}<0.01$ levels in both groups. Other blood parameters were found to be significantly different between the groups $(\mathrm{p}<0.05)$.
\end{abstract}

Keywords Football, Sedanter, Blood Parameters

\section{Introduction}

Football is a high-end sporting discipline in which both aerobic and anaerobic effort are used interchangeably with motor performance, such as strength, speed, flexibility, agility, cardiovascular and muscular endurance and coordination abilities[1]. In sports branches, body composition is regulated while increasing strength, strength, speed and flexibility with regular and load-bearing training based on scientific basis. While an optimal speed cannot be created with a muscular system lacking strength, the importance of durability in sports disciplines cannot be denied [2].
Regular training also affects lipid metabolism and causes changes in plasma lipid and lipoprotein levels. However, it is also stated that these positive effects of regular training are at different levels according to the type of gymnastics and sportsmen [3]. It has been widely suggested that regular exercise is effective in protecting against coronary risk factors with positive effects on lipid profiles $[4,5]$. In relation to the type and duration of exercise, however, researchers have reported conflicting results about the fact that in recent years they have led to beneficial changes in lipid metabolism [6,7].

In this study, it is aimed to compare some selected blood parameters with football players and Sedentary subjects with height, body weight, BMI.

\section{Method}

A total of 20 people was included in the study, including ten Sedentary with a mean age of $21.67 \pm 3.90$ years and 10 footballer whose mean age of $28.60 \pm 4.11$ years. It has been determined how many years football has been played by football players. It was seen that the average age of these sports was $7.11 \pm, 72$ years. The group playing football as an amateur is doing training on weekends for 1.5-2 hours a day. The height and body weight values of all subjects were determined. Later, blood samples were taken from the subjects to a pre-arranged health facility. It was asked that subjects should be hungry. Blood samples were taken approximately one month after the end of the competition. After examining on the blood samples, the obtained data was transferred to the digital environment. In the analysis of these data, $t$ test was used in SPSS 21 package program.

\section{Results}

When Table 1 was examined, it was determined that the average body weight of football players was $72.67 \pm 10,48$ $\mathrm{kg}$ and that of sedentary subjects were $81,90 \pm 7,59 \mathrm{~kg}$. It 
was also seen that the average height length was $80,11 \pm$ $5,62 \mathrm{~cm}$ for football players and $173,10 \pm 4,25 \mathrm{~cm}$ for sedentary subjects. The mean values of the participants' BMI were $22,30 \pm 2,22 \mathrm{~kg} / \mathrm{m}^{2}$ in football players and $27,32 \pm 2,10 \mathrm{~kg} / \mathrm{m}^{2}$ in sedentary subjects. The mean value of cholesterol in football players is $152,67 \pm 23,168 \mathrm{mg} / \mathrm{dl}$ whereas the mean in sedentary subjects is $173,10 \pm 32,52$ $\mathrm{mg} / \mathrm{dl}$. The average of HDL players playing football is $40,44 \pm 9,50 \mathrm{mg} / \mathrm{dl}$ whereas it is $36,00 \pm 10,73 \mathrm{mg} / \mathrm{dl}$ in sedentary subjects. The averages of LDL in football players and sedentary subjects are $82,67 \pm 14,44 \mathrm{mg} / \mathrm{dl}$ and $99,14 \pm 36,54 \mathrm{mg} / \mathrm{dl}$, respectively. The mean levels of serum iron levels in participants were $89,78 \pm 21,49 \mathrm{mg} / \mathrm{dl}$ in football players and $102,70 \pm 15,69 \mathrm{mg} / \mathrm{dl}$ in sedentary subjects. When the mean values of blood calcium in the sa me table were examined, it was seen that they were 9,76 \pm , $44 \mathrm{mg} / \mathrm{dl}$ in football, 9,35, $\pm 46 \mathrm{mg} / \mathrm{dl}$ in sedentary subjects. The average value of serum sodium values is
$140,67 \pm 1,22 \mathrm{mmol} / 1$ for football players and 138,90 \pm $1,73 \mathrm{mmol} / 1$ for sedentary subjects. When the blood MCV values were examined, it was found that $87,77 \pm 1,62 \mu \mathrm{m}^{3}$ in football players and $85,86 \pm 7,72 \mu \mathrm{m}^{3}$ in sedentary subjects. Again, when the averages of the HGB groups were examined, it was seen that this value was $15,35 \pm 43 \mathrm{~g}$ / dl for football players and $16,01 \pm 1,06 \mathrm{~g} / \mathrm{dl}$ for sedentary subjects. The mean values of $\mathrm{MCH}$ are $29,25 \pm 1,93 \mathrm{pg}$., $28,12 \pm 2,62 \mathrm{pg}$. in football players and sedentary subjects, respectively. The average value of serum MCHC was $33,44 \pm 2,27 \mathrm{~g} / \mathrm{dl}$ in football players, while it was $32,85 \pm$ $1,64 \mathrm{~g} / \mathrm{dl}$ in sedentary subjects. Again, the PLT average of football players is $163,00 \pm 24,90 \mathrm{~mm}^{3}$ and the sedentary subjects is $222,15 \pm 41,59 \mathrm{~mm}^{3}$. The mean value of the WBC's football players is $4,98 \pm 1,25 \mathrm{~mm}^{3}$, while this value is $5,66 \pm 2,28 \mathrm{~mm}^{3}$ for sedentary subjects, $45,95 \pm$ $2,39 \%$ for football players, and $49,03 \pm 3,02 \%$ for sedentary subjects.

Table 1. Mean Values and Significance Levels of Some Variables in Football Sessions and Sedentary subjects

\begin{tabular}{|c|c|c|c|c|c|c|}
\hline Variables & Groups & $\mathrm{N}$ & Mean & $\begin{array}{c}\text { Standard } \\
\text { Deviation }\end{array}$ & $\mathrm{t}$ & $\mathrm{P}$ \\
\hline \multirow{2}{*}{ Weight (kg) } & Footballer & 10 & 72.67 & 10.48 & \multirow{2}{*}{2.217} & \multirow{2}{*}{.041} \\
\hline & Sedentary & 10 & 81.90 & 7.59 & & \\
\hline \multirow{2}{*}{ Height $(\mathrm{cm})$} & Footballer & 10 & 180.11 & 5.62 & \multirow{2}{*}{-3.085} & \multirow{2}{*}{.007} \\
\hline & Sedentary & 10 & 173.10 & 4.25 & & \\
\hline \multirow{2}{*}{ BMİ $\left(\mathrm{kg} / \mathrm{m}^{2}\right)$} & Footballer & 10 & 22.30 & 2.22 & \multirow{2}{*}{5.053} & \multirow{2}{*}{.000} \\
\hline & Sedentary & 10 & 27.32 & 2.10 & & \\
\hline \multirow{2}{*}{ Cholesterol (mg/dl) } & Footballer & 10 & 152.67 & 23.168 & \multirow{2}{*}{1.560} & \multirow{2}{*}{.137} \\
\hline & Sedentary & 10 & 173.10 & 32.52 & & \\
\hline \multirow{2}{*}{ HDL (mg/dl) } & Footballer & 10 & 40.44 & 9.50 & \multirow{2}{*}{-.951} & \multirow{2}{*}{.355} \\
\hline & Sedentary & 10 & 36.00 & 10.73 & & \\
\hline \multirow{2}{*}{ LDL (mg/dl) } & Footballer & 10 & 82.67 & 14.44 & \multirow{2}{*}{1.264} & \multirow{2}{*}{.223} \\
\hline & Sedentary & 10 & 99.14 & 36.54 & & \\
\hline \multirow{2}{*}{$\operatorname{Iron}(\mathrm{mg} / \mathrm{dl})$} & Footballer & 10 & 89.78 & 21.49 & \multirow{2}{*}{1.508} & \multirow{2}{*}{.150} \\
\hline & Sedentary & 10 & 102.70 & 15.69 & & \\
\hline \multirow{2}{*}{ Calcium(mg/dl) } & Footballer & 10 & 9.76 & .44 & \multirow{2}{*}{-1.955} & \multirow{2}{*}{.067} \\
\hline & Sedentary & 10 & 9.35 & .46 & & \\
\hline \multirow{2}{*}{ Sodium(mmol/l) } & Footballer & 10 & 140.67 & 1.22 & \multirow{2}{*}{-2.542} & \multirow{2}{*}{.021} \\
\hline & Sedentary & 10 & 138.90 & 1.73 & & \\
\hline \multirow{2}{*}{$\operatorname{MCV}\left(\mu \mathrm{m}^{3}\right)$} & Footballer & 10 & 87.77 & 1.62 & \multirow{2}{*}{-.726} & \\
\hline & Sedentary & 10 & 85.86 & 7.72 & & .478 \\
\hline & Footballer & 10 & 15.35 & .43 & & \\
\hline HGB (g/dl) & Sedentary & 10 & 16.01 & 1.06 & 1.734 & .101 \\
\hline & Footballer & 10 & 29.25 & 1.93 & & 201 \\
\hline МCH (pg.) & Sedentary & 10 & 28.12 & 2.62 & -1.067 & .301 \\
\hline & Footballer & 10 & 33.44 & 2.27 & 654 & 520 \\
\hline $\mathrm{MCHC}(\mathrm{g} / \mathrm{dl})$ & Sedentary & 10 & 32.85 & 1.64 & -.654 & .522 \\
\hline PI T $\left(\mathrm{mm}^{3}\right)$ & Footballer & 10 & 163.00 & 24.90 & 3705 & 002 \\
\hline PLI (mm ) & Sedentary & 10 & 222.15 & 41.59 & 3.705 & .002 \\
\hline & Footballer & 10 & 4.98 & 1.25 & 792 & 430 \\
\hline WBC $\left(\mathrm{mm}^{3}\right)$ & Sedanter & 10 & 5.66 & 2.28 & .792 & .439 \\
\hline & Footballer & 10 & 45.95 & 2.39 & & \\
\hline НCT (\%) & Sedentary & 10 & 49.03 & 3.02 & 2.441 & .026 \\
\hline
\end{tabular}




\section{Conclusion and Discussion}

When the subjects participating in the study, body weight average, football players and sedentary subjects were examined, it was seen that the players who played football had a body weight of $72,67 \pm 10,48 \mathrm{~kg}$ and the sedentary subjects had body weight of $81,90 \pm 7,59 \mathrm{~kg}$. The difference between these mean values was statistically significant $(\mathrm{p}<0,05)$. In his study, Okan[8] found that a significant reduction in athletes' body weights occurred after the training program. Temur et al.[9] reported significant reductions in body weights after exercise program in women's work.

When the average height lengths of the football players and the sedentary subjects were examined, it was determined that the average height lengths of footballers were $180,11 \pm 5,62 \mathrm{~cm}$ and those values in sedentary subjects were $173,10 \pm 4,25 \mathrm{~cm}$. When there was a statistically significant difference between these values, it was seen that there was a difference at the level of $p<0,01$. Danac1[10] reported that there was no significant difference between the averages of sportsmen and sedentary subjects. The result of the study can be explained by the favorable effect of genetic factors on length, nutrition, exercise on bone and skeletal system, as well as the preference of taller in football player selection.

When the averages of BMI values in the groups were examined, it was determined that football players had an average of $22,30 \pm 2,22 \mathrm{~kg} / \mathrm{m}^{2}$ and sedentary subjects had an average of $27,32 \pm 2,10 \mathrm{~kg} / \mathrm{m}^{2}$. When these two mean values were statistically compared, a significant difference was found at $\mathrm{p}<0,01$ level. Yalın et al.,[11] and Wong et al.,[12] reported that while the BKI values did not change, the studies conducted by Büyükyaz1 et al[13] reported that they were diminishing their work.

When the average cholesterol values of both groups were examined, it was found that football players had an average of $152,67 \pm 23,168 \mathrm{mg} / \mathrm{dl}$ and sedentary subjects had an average of $173,10 \pm 32,52 \mathrm{mg} / \mathrm{dl}$. It was found that the difference between these mean values was not statistically significant $(\mathrm{p}<0,05)$. Exercise has been reported to affect lipid metabolism positively. It has been reported to cause a decrease in total cholesterol and serum triglycerides [14]. The findings of the study are consistent with the literature. Although the findings are less statistically significant, it is thought that the average age of the control group may be effective. In addition, a reduction in body weight and fat ratio resulting from exercise may be effective in reducing serum cholesterol.

The average HDL values of football players were 40,44 $\pm 9,50 \mathrm{mg} / \mathrm{dl}$, while those of sedentary subjects were $36,00 \pm 10,73 \mathrm{mg} / \mathrm{dl}$. There was no statistical difference between these mean values. The median value of LDL in football players is $82,67 \pm 14,44 \mathrm{mg} / \mathrm{dl}$, and in sedentary subjects is $99,14 \pm 36,54 \mathrm{mg} / \mathrm{dl}$. It was found that these values were not statistically significant $(p<0,05)$. Büyükyazi[13] and Lakka et al.,[14] reported that changes in the HDL values of exercise were associated with an increase in HDL values after exercise, while Enger et al[7] and Tran et al.[15] they did not cause it. Nicklas et al.[16] reported that the effect of exercise on HDL was related to weight, body fat distribution, duration and severity of exercise, and weight loss with exercise. Gaesser and Rich,[17] reported that low and high intensity exercises did not significantly affect HDL values in young men with low blood lipid levels. It is thought that the average age of both study groups may be effective for such a result.

When the serum iron levels of the subjects were examined according to the groups, it was determined that the average value of football players was $89,78 \pm 21,49 \mathrm{mg}$ / $\mathrm{dl}$, and that of sedentary subjects was $102,70 \pm 15,69 \mathrm{mg}$ / dl. The difference between these mean values was not statistically significant (p < <0,05). Clement and Asmundson[18] found that $82 \%$ of female athletes had ferritin levels below $25 \mathrm{mg} / \mathrm{L}$. In another study, $40 \%$ of the runners and $47 \%$ of the swimmers were found to have iron deficiency, which was $27 \%$ in the control group [19]. The literature supports the findings of the study. The reason for this lack of iron may be due to inadequate feeding despite the effort.

Mean values of serum calcium were found to be $9,76 \pm$, $44 \mathrm{mg} / \mathrm{dl}$ in the football-playing group and 9,35 $\pm 46 \mathrm{mg} /$ $\mathrm{dl}$ in the sedentary subjects. It was found that these values were not significantly different $(\mathrm{p}<0,05)$. Calcium may become infiltrated into the tissue to produce muscle contractions during exercise, and blood levels may decrease during exercise [20]. Mashiko, et al.[21] reported that pre-and post-camp calcium levels were $9,2 \pm 0,2 \mathrm{mg} /$ $\mathrm{dL}$ and $90 \pm 0,4 \mathrm{mg} / \mathrm{dL}$, respectively. The findings of the study are similar to the literature.

Another finding is that Football players have average sodium values of $140,67 \pm 1,22 \mathrm{mmol} / 1$ and sodium average of sedentary subjects of 138,90 $\pm 1,73 \mathrm{mmol} / 1$. It was observed that the difference between these two values was not statistically significant $(\mathrm{p}<0,05)$. Mashiko, et al.[21] reported that pre and post-camp sodium values on rugby players did not differ significantly in striker players, but in defensive players. Under normal conditions, a daily average of $500 \mathrm{ml}$ of body fluid, $400 \mathrm{ml}$ of lungs, $1500 \mathrm{ml}$ of urine and $200 \mathrm{ml}$ of fluid is lost through the human body [22]. During the intense exercise in hot environments, the primary pathway of heat loss is the evaporation of the sweat layer, which accumulates on the skin [23]. Exercise performance and health of the individual can be adversely affected [24].

Mean MCV values were $87,77 \pm 1,62 \mu \mathrm{m}^{3}$ in football players and $85,86 \pm 7,72 \mu \mathrm{m}^{3}$ in non-sportsmen. This was not statistically significant ( $p<0,05)$, although the average was higher in football players. Two different studies on women [25] and men[26] previously encountered different results. When these results affect the blood values of the exercise, the duration of the exercise, the severity and how long the blood samples are taken after exercise are important.

When the serum is at hemoglobin level, it is $15,35 \pm 43 \mathrm{~g}$ / $\mathrm{dl}$ in football players and $16,01 \pm 1,06 \mathrm{~g} / \mathrm{dl}$ in sedentary subjects. There was no statistically significant difference ( $p$ $<0,05)$ between them. In their study, Berne and Matthew 
[27] reported that average athletes with hemoglobin levels of $16 \mathrm{~g} / \mathrm{dL}$ athletes participated in the Olympics in different sports. It is known that hemoglobin concentration is related to muscular activity. As the severity of muscular activity increases, the amount of hemoglobin increases as the oxygen requirement increases.

The MCH values of the groups are $29.25 \pm 1,93 \mathrm{~g} / \mathrm{dl}$ and $28,12 \pm 2,62 \mathrm{~g} / \mathrm{dl}$ respectively in football and sedentary subjects. The difference between the two values was not significant $(p<0,05)$. In this regard, Koç et al.[28] and İbiş et al.[29] found results in support of the findings of their studies.

When the serum MCHC levels of the participants were considered in groups, it was determined that football players had an average of $33.44 \pm 2,27 \mathrm{~g} / \mathrm{dl}$ and sedentary subjects had an average of $32,85 \pm 1,64 \mathrm{~g} / \mathrm{dl}$. It was observed that these values close to one were not significant $(\mathrm{p}<0.05)$ difference. Demiriz et al. [30] reported a significant $(p<0.01)$ increase in MCHC levels in their study. Suggesting that exercise in Temur 2018 study resulted in a significant increase in MCHC values [25]. It is believed that blood samples may be effective if taken one month after the end of the ligaments when the findings are inconsistent with the literature.

The PLT values of the footballers who were included in the study were $163.00 \pm 24,90 \mathrm{~mm} 3$ and the mean of the sedentary subjects was $222,15 \pm 41,59 \mathrm{~mm} 3$. The difference between these mean values was found to be statistically significant $(p<0.01)$. Rietjens et al. [31] reported that there was no significant difference in PLT values when they were studying on a total of 11 Olympic athletes, 7 males and 4 females.

When the serum WBC values of the subjects were examined in both groups, it was determined that the average value of these values in football players was $4.98 \pm$ $1.25 \mathrm{~mm}^{3}$ and in sedentary subjects were $5,66 \pm 2,28 \mathrm{~mm}^{3}$. No statistically significant difference $(\mathrm{p}<0.05)$ was found between these two values. There are studies showing no significant difference in serum WBC values after the training [31, 32].

The mean values of serum HCT in football players were found to be $45.95 \pm 2.39 \%$ and $49.03 \pm 3.02 \%$ in sedentary subjects. When these values were compared statistically, it was seen that there was a difference at $p<0.05$ level. Temur[25] showed that HTC values before and after exercise were not significantly different. On the other hand, it was reported that there was a significant increase in hematocrit level immediately after exercise and decreased to normal level approximately 24-48 hours after the exercise $[33,34]$.

\section{REFERENCES}

[1] Eniseler, N. "Physiological Factors Affecting Football", Football Science and Technology journal, 1994, 1,10-12.

[2] Kartal, R., Günay, M., "Influence of pre-season preparatory training on some physiological parameters of footballers", Hacettepe University Sports Science journal, 1994, 5(3), 24-31.

[3] Arslan, E., Kelle M., Baylan Y., Diken H., Atmaca, M., Tümer, C., Obay, B., Şermet, A. Comparison of Plasma Lipid Levels in Sports between Self and Controls. Dicle Medical Journal (Journal Ofedical School) 2001,28(1), 23-34.

[4] Criqui, Mh.; Epidemiology of atherosclerosis. Am. J. Cardiol, 1986, 57:18-23.

[5] Emerk, K., Onat, T; Lipids. Basic biochemistry. Saray Medical Publishing, 1997, İzmir, s: 409- 489.

[6] Cullinane, E., Lararus, B., Thompson, Pd; Acute effect of a single exercise session on serum lipids in untrained men. Clin. Chim. Arta. 1981,109:241-4.

[7] Enger, Cs., Herbjrnsen, J., Fretland, A; HDL-C and physical activity: The influence of physical exercise age and smoking on HDL-C and HDL-C/ total kolestrol ratio. Scand J. Clin. Lab. Invest. 1997, 37:251-255.

[8] Okan İ. Effects of Future Technique, Endurance and Speed Studies on Some Physiological Parameters of Young Soccer Players GÜ, Gazi Faculty of Education journal, 2009,Cilt 29, $\mathrm{S}, 3,673-692$.

[9] Temur, H.B., Öztürker, M., Karaman, M. E., Selçuk, M., Çinar, V. Effect Of Eight Weeks Exercise On Body Composition And Some Blood Values In Women. European Journal of Physical Education and Sport Science, 2017, Volume 3, Issue 11.

[10] Danac1 M. Determination of Sport Approach, Physical Constitution and Physiomotor Features of Adolescents Sedanter and Sportsmen Male Students Who Study in Different Types of High Schools in Adana Province, Adana, Çukurova University Health Sciences Institute Graduate Thesis, 2008.

[11] Yalın, S. Gök, H. Toksöz, R. Effects of Short-Term Regular Exercise-Diet Program on Lipid Profiles in Sedanter Individuals. Ana Kar Der, 2001, 1: 179-188.

[12] Wong, P.C.H., Chia, M.Y.H., Tsou, I.Y.Y., Wansaicheong, G.K.L., Tan, B., Wang, J.C.K., Tan, J., Kim, C.G., Boh, G., Lim, D. Effects of A 12-Week Exercise Training Programme on Aerobic Fitness, Body Composition, Blood Lipids and C-Reactive Protein in Adolescents with Obesity. Ann Acad Med Singapore, 2008, 37: 286-93.

[13] Büyükyazı, G., Ulman, C., Taneli, F., Aksoy, D., Tıkız, H. Effects of Walking on Serum Lipids, MMP-9 And TIMP-1 in Post-Menopausal Women. 10th International Sport Congress, 2008, Bolu, Turkey.

[14] Lakka, H.M., Tremblay A., Després J.P., Bouchard C. Effects of Long-Term Negative Energy Balance With Exercise on Plasma Lipid and Lipoprotein Levels in İdentical Twins. Atherosclerosis, 2004, 172: 127-133.

[15] Tran, Z.V., Weltman, A., Glass, G.V., Mood, D.P. The Effects of Exercise on Blood Lipids and Lipoproteins. Medicine and Science in Sport and Exercise, 15(5): 392-402, 1983.

[16] Nicklas, B.J., Katzel, L.I., Busby W.J., Goldberg, A.P. 
Increases in High-Densitiy Lipoprotein Cholesterol with Endurance Exercise Traning are Blunted in Obese Compared with Lean Men. Metabolism, 1997, 46(5): 556-561.

[17] Gaesser, G.A., Rich, R.G. Effects of High-and LowIntencity Exercise Training on Aerobic Capacity and Blood Lipids. Med Scie Sports Exerc. 1984,16(3):269-274.

[18] Clement DB, Asmundson RC. Nutritional intake and hematological parameters in endurance runners. Physician Sport Med; 1982, 10(3): 37-43.

[19] Rowland TW, Kelleher JF. Iron deficiency in athletes:insights from high school swimers .Am J Dis Child; 1989, 143: 197-200.

[20] Guyton MD, Hall JE: T1bbiFizyoloji. "Textbook of Medical Physiology"dençev: ÇavuşoğluH, 9ncu baskı, İstanbul, YüceYayınları, Alemdar Ofset, 1996.

[21] Mashiko,T., Umeda, T., Nakaji, S., Sugawara, K.. Effects of exercise on the physical condition of college rugby players during summer training camp, Br J Sports Med ; 2004, 38:186- 190. doi: 10.1136/bjsm.2002.004333.

[22] Shirreffs, S.M. “Markers of Hydration Status", J Sports Med Phys Fitness, Mar; 2000, 40(1):80-4.

[23] Sharp, R.L. "Role Of Sodium in Fluid Homeostasis With Exercise", J Am CollNutr, 2006, Vol.25, No. 3, 231s-239s.

[24] Sawka, M.N, Burke, L.M, Eichner, E.R, Maughan, R .J, Montain, S. J, Stachenfeld, N .S. "Exercise and fluid replacement."American College of Sports Medicine, Med Sci Sports Exerc, 2007, Volume 39 - Issue 2 - pp 377-390.

[25] Temur H.B. Investigation of Exercise Relation to Some Blood Parameters. Journal of Social And Humanities Sciences Research, 2018, Vol:5 Issue:17 pp:253-257.
[26] Temur, B.Evaluation Of Muscle Damage And Changes In Some Blood Parameters Before and After An Intercolleguate Footbal Tournament, International Journal of Recent Scientific Research, 2018, Vol. 9, Issue, 4(B), pp. 25628-25630, April.

[27] Berne, R. M., Matthew, N. Cardiovascular physiology; Newyork, Eight edition, 2001, 272-278.

[28] Koç, H., Saritaş, S., Büyükipekci, S. Comparison Of Social Hematological Levels of Sports And Sedanters, Journal Of Health Sciences 2010,19 (3) 196-201.

[29] İbiş S, Hazar S, Gökdemir K. The effects of aerobic and anaerobic exercises on hematological parameters acute effect. 10th International Sports Science Congress. 2008, October, 23-25, Bolu.

[30] Demiriz, M., Erdemir İ. Kayhan, R.F. Effects of Anaerobic Interval Training with Different Rest Interval on Aerobic Capacity, Anaerobic Threshold and Blood Parameters, Sports, Exercise and Training Science, 2015, 1, 1, 1-8.

[31] Rietjens, G.J., Kuipers, H., Hartgens, F., \& Keizer, H.A. Red Blood Cell Profile of Elite Olympic Distance Triathletes. A thre-year follow-up. Int. J. Sports Med, 2002, 23(6):391-6.

[32] Banfi G., Del Fablo M., Mauri C.,Corsi M.M. \&Melegati, G. HaematologicalParameters in Higly Elite Rugby Players During A Competitive Season. Jun Pub Med -Indexed For Medline, 2006, 28(3): 183-8.

[33] Wade E., Ramee R., Hunt M., \& While J. Hormonal and renal responses to converting enzyme inhibition during maximal exercise. J ApplPhysiol, 1987, 63, 1796-800.

[34] Ersöz G., Köksoy A., Zergeroğlu A., Yavuzer S. Acute-chronic physical exercise and immunglobulins. Journal of Sports Sciences, 1995, 6, 3, 3-12. 